NASA Technical Memorandum 107055

AIAA-95-2397

\title{
$112-20$
}

\section{Evaluation of Rhenium Joining Methods}

Brian D. Reed and Sybil H. Morren

Lewis Research Center

Cleveland, Ohio

Prepared for the

31st Joint Propulsion Conference and Exhibit

cosponsored by AIAA, ASME, SAE, and ASEE

San Diego, California, July 10-12, 1995

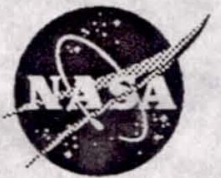

National Aeronautics and Space Administration

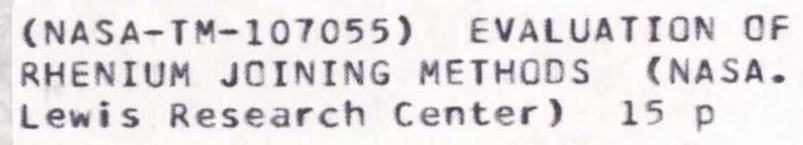




\section{EVALUATION OF RHENIUM JOINING METHODS}

Brian D. Reed and Sybil H. Morren NASA Lewis Research Center Cleveland, Ohio

\begin{abstract}
Coupons of rhenium-to-C103 flat plate joints, formed by explosive and diffusion bonding, were evaluated in a series of shear tests. Shear testing was conducted on as-received, thermally-cycled (100 cycles, from 21 to $1100^{\circ} \mathrm{C}$ ), and thermally-aged ( 3 and 6 hrs at $1100^{\circ} \mathrm{C}$ ) joint coupons. Shear tests were also conducted on joint coupons with rhenium and/or $\mathrm{C} 103$ electron beam welded tabs to simulate the joint's incorporation into a structure. Ultimate shear strength was used as a figure of merit to assess the effects of the thermal treatment and the electron beam welding of tabs on the joint coupons. All of the coupons survived thermal testing intact and without any visible degradation. Two different lots of as-received, explosively-bonded joint coupons had ultimate shear strengths of 281 and $310 \mathrm{MPa}$ and 162 and $223 \mathrm{MPa}$, respectively. As-received, diffusionbonded coupons had ultimate shear strengths of 199 and $348 \mathrm{MPa}$. For the most part, the thermallytreated and rhenium weld tab coupons had shear strengths slightly reduced or within the range of the as-received values. Coupons with $\mathrm{C} 103$ weld tabs experienced a significant reduction in shear strength. The degradation of strength appeared to be the result of a poor heat sink provided during the electron beam welding. The $\mathrm{C} 103$ base material could not dissipate heat as effectively as rhenium, leading to the formation of a brittle rhenium-niobium intermetallic.
\end{abstract}

\begin{tabular}{ll} 
& \multicolumn{1}{c}{ Nomenclature } \\
ASTM & American Society for Testing Materials \\
$\mathrm{Au}$ & gold \\
$\mathrm{C} 103$ & niobium-hafnium-titanium alloy \\
$\mathrm{Cu}$ & $\begin{array}{l}\text { copper } \\
\text { chemical vapor deposition }\end{array}$ \\
$\mathrm{CVD}$ & electron beam \\
$\mathrm{EB}$ & electrical discharge machining \\
EDM & energy dispersive spectroscopy \\
EDS & hafnium
\end{tabular}

$\begin{array}{ll}\mathrm{Ir} & \text { iridium } \\ \mathrm{Ir} / \mathrm{Re} & \text { iridium-coated rhenium } \\ \mathrm{LOX} & \text { liquid oxygen } \\ \mathrm{MMH} & \text { monomethylhydrazine } \\ \mathrm{Mo} & \text { molybdenum } \\ \mathrm{Nb} & \text { niobium } \\ \mathrm{NTO} & \text { nitrogen tetroxide } \\ \mathrm{Ni} & \text { nickel } \\ \mathrm{N} 2 \mathrm{H} 4 & \text { hydrazine } \\ \mathrm{Pd} & \text { palladium } \\ \mathrm{Pt} & \text { platinum } \\ \mathrm{Re} & \text { rhenium } \\ \mathrm{Rh} & \text { rhodium } \\ \mathrm{SS} & \text { stainless steel } \\ \mathrm{Ta} & \text { tantalum } \\ \mathrm{Ti} & \text { titanium }\end{array}$

\section{Introduction}

A material system composed of a $\mathrm{Re}$ substrate and an Ir coating has proven to provide high-temperature $\left(2200^{\circ} \mathrm{C}\right)$, long-life (hours) operation for radiation-cooled rockets operating on Earth storable propellants (ref 1). There is an ongoing effort to develop flighttype, Ir/Re engines, particularly at the 440-N thrust level (ref. 2).

Complementing this effort is a more fundamentalsoriented radiation-cooled rocket material program, including evaluation of methods for joining $\operatorname{Re}$ to dissimilar metals. The focus of this study was the joining of $\mathrm{Re}$ to $\mathrm{ClO3}$.

$\mathrm{Ir} / \mathrm{Re}$ chambers require joining $\mathrm{Re}$ to an injector and a nozzle skirt composed of dissimilar metals. Common injector materials include 304L SS, C103, and Ti. Since Re is a relatively heavy material and its high temperature capability is not needed throughout the nozzle, the Ir/Re chamber can be truncated at a low area ratio and a lighter refractory, such as $\mathrm{C} 103$, used for the nozzle skirt. The configuration of injector-to-chamber and the chamber-to-nozzle joints vary depending on the specific engine design. Often the joints are designed not to bear any major mechanical loads, so that the primary requirement for the joint would be to seal against hot combustion gases. In operation of the engine, the joints will be subjected to thermal cycling. The range, number, and duration of the 
thermal cycles are dependent on the particular application.

EB welding would be an attractive production method for joining $R e$ chambers to injectors and nozzles. Direct EB welding of Re to C103, however, has been found to form brittle joints due to a brittle Re-Nb intermetallic that forms at $2162^{\circ} \mathrm{C}$. The presence of the brittle intermetallic prevents the use of fusion welding methods (melting of material) for joining Re chambers to $\mathrm{C} 103$ nozzle skirts. As a result, brazing and nonfusion welding have been investigated for joining Re-to-C103. This paper will survey $R e$ joining technology programs and present an evaluation of two Re-to-C103 joining methods: explosive bonding and diffusion bonding. The joining methods would be used to form a bimetal joint or transition piece, to which the Re chamber and $\mathrm{C} 103$ nozzle could be EB welded. The joint evaluation involved the thermal cycling, thermal aging, welding, and shear testing of flat plate coupons. Test results and posttest metallography will be discussed.

\section{Re to Dissimilar Metals Joining Review} In an $\mathrm{Ir} / \mathrm{Re}$ engine technology program, Aerojet (ref. 1) investigated different methods of joining Re to $304 \mathrm{~L}$ SS, Hastelloy B2, and unalloyed $\mathrm{Nb}$. Inertia welding of Re-to- $\mathrm{Nb}$ produced a strong joint, but the technique was ineffective for Re-to304L SS and Re-to-Hastelloy B2 joints. Five braze filler alloys were evaluated for their wetting ability: Palcusil 25, Silcoro 75, Palsil 10, Nioro (82Au$18 \mathrm{Ni}$ ), and $50 \mathrm{Au}-50 \mathrm{Cu}$. Good to excellent wetting was found for all the braze alloys on $\mathrm{Re}, 304 \mathrm{~L} \mathrm{SS}$, and Hastelloy B2. For Nb, however, Silcoro 75 and $50 \mathrm{Au}-50 \mathrm{Cu}$ was found only to wet marginally well. Palcusil 25 and Nioro were investigated further in lap and ring shear testing. Both of these braze alloys demonstrated strong joints, though Nioro joints tended to be stronger. Nioro was recommended as a brazing alloy for Re-to-304L SS joints, since no intermetallics were indicated in the Au-Re and $\mathrm{Ni}-\mathrm{Re}$ phase diagrams. Furnace brazing using Nioro was utilized in joining a 304L SS injector, a Pt-10Rh trip ring, and an $\mathrm{Ir} / \mathrm{Re}$ chamber for a $62-\mathrm{N}$ flighttype engine (ref. 3).

Re-to-Nb joints produced by EB welding were found to be brittle, due to the formation of a brittle intermetallic phase that forms above $2162{ }^{\circ} \mathrm{C}$. This intermetallic phase probably formed during the solidification of the weld and was retained in a metastable condition at room temperature. Re-to304L SS and Re-to-Hastelloy B2 joints were achieved using a "parent metal braze" technique. Here only the 304L SS and Hastelloy B2 were melted, wetting the $\mathrm{Re}$ and solidifying to form the joint.

The parent metal braze technique was utilized by Aerojet in joining a 304L SS adapter piece to a Re chamber for a high performance $440-\mathrm{N}$ flighttype engine (ref. 4). The SS injector was then EB welded to the 304L SS adapter. On the same 440-N engine, joining of the Re chamber to the C103 nozzle skirt was accomplished using the method illustrated in figure 1 . A Re/C103, bi-metal ring was formed by the application of CVD Nb over $\mathrm{Re}$ and $\mathrm{Cl} 103$ pieces. The $\mathrm{Re}$ chamber was then EB welded to the $\operatorname{Re}$ side of the bi-metal ring, while the $\mathrm{C} 103$ skirt was EB welded to the $\mathrm{C} 103$ side.

The 440- $\mathrm{N}$ engine was tested for 80 full thermal cycles and over 6 hours on NTO/MMH propellants. The maximum temperature measured nearest to the injector joint (at the SS to SS EB weld) was $169^{\circ} \mathrm{C}$. The nozzle joint maximum temperatures were measured to be $1166^{\circ} \mathrm{C}$ and 1013 ${ }^{\circ} \mathrm{C}$, on the $\mathrm{Re}$ and $\mathrm{C} 103$ sides of the joint, respectively. The injector and nozzle joints survived testing intact. The nozzle joint failed from the exterior, after testing was over, due to oxygen embrittlement of uncoated C103. This type of failure would not have occurred in ground tests if the nozzle exterior was coated with disilicide or in actual operation in the vacuum of space.

TRW (ref. 5) investigated methods of joining Re-to- $\mathrm{C} 103$ in a development program for a LOX/N2H4, 440-N class engine. Direct EB welding of $\mathrm{Re}$-to-C103 resulted in cracking in the weld due to the formation of a brittle intermetallic phase between $\mathrm{Re}$ and $\mathrm{Nb}$ (as was seen in reference 3 ). Thin $(0.43$ $\mathrm{cm}) \mathrm{Mo}, \mathrm{Ti}$, and $\mathrm{Ta}$ shims were evaluated as filler materials to the EB weld. All of the Re-to-C103 welds tried with these filler materials cracked and separated. A Ti filler shim twice the width $(0.089$ $\mathrm{cm}$ ) of the others, showed no signs of cracking. However the Ti formed a brittle intermetallic phase with Re resulting in low tensile strength. 
Several braze materials were evaluated for furnace brazing of Re-to-C103, including 65Au-35Pd, 50Au-50Pd, and Ti. These three braze joint samples were subjected to thermal aging ( 4 hours at $1200^{\circ} \mathrm{C}$ ) and thermal cycling (room temperature to $1200^{\circ} \mathrm{C}$ for 20 cycles) tests. The Ti sample showed a small crack at the braze/Re interface, due to the formation of a brittle phase. The 50Au-50Pd sample showed void areas where there was poor flow of braze and shrinkage forming cracks. The $65 \mathrm{Au}-35 \mathrm{Pd}$ sample showed only some small voids and no diffusion of the braze material into Re or C103. Diffusion of $\mathrm{Nb}$ and $\mathrm{Hf}$ (from the $\mathrm{ClO} 3$ alloy) into the braze was found, however. Based on this investigation, the 65Au-35Pd braze alloy was recommended for furnace brazing Re-to-C103. TRW is investigating alternatives to brazing, including the use of bi-metal joints fabricated by inertia welding (ref. 6).

Brazing has been investigated most extensively as an alternative to $\mathrm{EB}$ welding for joining Re chambers to injectors and $\mathrm{C} 103$ nozzle skirts. However, there are potential problems that can arise with braze joints. The brazing process often requires a complex design at the interfaces to properly wet the joining area. Braze layers are relatively thin and have limited strength, raising concerns about the joint's ability to survive the severe vibrational environment experienced during launch and under repeated pulsing of the rocket. Furthermore, most braze materials have limited temperature and thermal cycling capabilities.

A bi-metal ring or tube, as illustrated in figure 2, could be used as a separate transition piece rather than directly joining the chamber to the injector or nozzle. The bi-metal piece can be fabricated using a nonfusion (non-melting) bonding process, thereby avoiding the brittle Re- $\mathrm{Nb}$ intermetallic seen with EB welding. The Re chamber would then be $\mathrm{EB}$ welded to Re side of the bi-metal joint and $\mathrm{C} 103$ can be $\mathrm{EB}$ welded to the $\mathrm{C} 103$ side of the joint. (There are no inherent problems with $\mathrm{EB}$ welding a material to itself). This same concept can be used to join Re to other metals. Use of a transition piece allows a great amount of flexibility in the joint design. Plates or tubes of $\mathrm{Re}$ and $\mathrm{ClO}$ can be joined by the nonfusion bonding process and easily machined into any suitable configuration. This study evaluates the use of explosive bonding and diffusion bonding for creating bi-metal joints.

\section{Bi-Metal Joining Techniques \\ Explosive Bonding \\ Explosive bonding is a high pressure} welding process that uses controlled explosive detonations to force two pieces together rapidly and at a low contact angle (refs. 7 and 8). The duration of the explosive bonding process is so short that the heat effected zone between the metals is microscopic. The bond line is an abrupt transition from one metal to the other, with virtually no degradation of the metals' mechanical properties. The explosive bond is nearly an ideal composite, that is, it is a metallurgical bond with virtually unaffected base materials. The formation of brittle intermetallics is avoided, since this is essentially an ambient temperature process (the generated heat cools very rapidly).

\section{Diffusion Bonding}

In diffusion bonding, temperature and pressure are applied uniformly to a piece to expand it into the other piece (ref. 8). The interdiffusion of the materials make up the joint in solid state. Since heating is uniform, the entire structure will undergo the same metallurgical changes and there will not be a heat-affected zone. The lack of fusion and heataffected zones give unaffected base materials, producing nearly an ideal composite. Diffusion bonding of $\mathrm{Re}$ to $\mathrm{Nb}$ and $\mathrm{Nb}$ alloys has been performed in technology programs for the SP- 100 nuclear reactor (ref. 9).

\section{Re-to-Cl03 Joint Coupons}

The Re plates used in this program were fabricated by powder metallurgy and further consolidated using hot isostatic pressure for a density greater than 98 percent of theoretical. The $\mathrm{Cl} 03$ plates had a composition of 89 percent $\mathrm{Nb}, 10$ percent $\mathrm{Hf}$, and $\mathrm{I}$ percent $\mathrm{Ti}$.

Two Re-to-C103, explosively-bonded plates, each approximately $5.1 \mathrm{~cm}$ by $15.2 \mathrm{~cm}$ by $1.11 \mathrm{~cm}$. were received from Northwest Technical Industries. The Re thickness was approximately $0.64 \mathrm{~cm}$, while the $\mathrm{C} 103$ was $0.48 \mathrm{~cm}$ thick. The two plates represented differences in the parameters used in the explosive bond process and were labeled lot \#2090 and lot \#2097, respectively. A sleeve-on-sleeve 
(tube) joint configuration could also be fabricated using explosive bonding, but was not evaluated in this study.

Two Re-to-C103, diffusion-bonded plates, each $5.1 \mathrm{~cm}$ by $2.2 \mathrm{~cm}$ by $0.80 \mathrm{~cm}$, were received from Advanced Methods and Materials. The Re thickness was approximately $0.32 \mathrm{~cm}$, while the $\mathrm{C} 103$ was $0.48-\mathrm{cm}$ thick. Each plate was fabricated using the same process parameters. A sleeve-onsleeve configured joint, essentially a diffusion-bonded tube with a $\mathrm{C} 103$ exterior and a $\mathrm{Re}$ interior, was also provided. Visual inspection showed it to be in excellent condition, although a detailed evaluation has not yet been performed.

Each of the explosively-bonded and diffusion-bonded plates were sectioned (using EDM) into sandwich and " $Z$ " coupon configurations, as shown in figure 3 . Figure 4 shows explosivelybonded coupons, while figure 5 shows diffusionbonded coupons. In each photo, $\mathrm{C} 103$ is the darker metal, while $\mathrm{Re}$ is the lighter metal. From visual inspections, all of the flat plate coupons evaluated in this study appeared to be in excellent condition, with no obvious defects or deformation at the bond line.

\section{Joint Evaluation Procedure}

Test Matrix

The evaluation of the $\mathrm{Re}$-to- $\mathrm{C} 103$ joints consisted of a series of thermal, welding, and shear tests, as listed in table I. Thermal cycling was performed to assess the integrity of the joint during an operational cycle. Thermal aging of samples were performed to determine if time at temperature would promote the formation of brittle intermetallics or degradation due to interdiffusion at the joint. EB welding of $\mathrm{Re}$ and/or $\mathrm{C} 103$ tabs to coupons was performed to determine if welding to the bi-metal joint would have any adverse effects. Nearly all of the coupons were shear tested after being subjected to thermal testing. Ultimate shear strength was used as a figure of merit to compare as-received coupons with thermally cycled and EB welded coupons.

Furthermore, shear testing would locate the weakest part of the diffusion zone, which generally will be the region with intermetallics.

\section{Thermal Testing}

As-received sandwich coupons of each type were subjected to thermal cycling tests. A total of 100 thermal cycles were performed, from 21 to 1100 ${ }^{\circ} \mathrm{C}$. The coupons were placed in an evacuated quartz vessel. The vessel was heated in a furnace to 1100 ${ }^{\circ} \mathrm{C}$ (the maximum furnace temperature) and immediately cooled to $21^{\circ} \mathrm{C}$ by quenching the vessel in water. From thermocouple measurements on the vessel exterior, the heating and cooling transients typically were 3 and 5 minutes, respectively. After thermal cycling the coupons were machined into the Z-configuration (using EDM) and shear tested.

An explosively-bonded (lot \#2090) and diffusion-bonded sandwich coupon were thermally aged in furnace with an inert environment, for 3 hours at $1100{ }^{\circ} \mathrm{C}$. Another diffusion-bonded sandwich coupon was thermally aged for 6 hours at $1100^{\circ} \mathrm{C}$. The diffusion-bonded coupons were EDMed into $\mathrm{Z}$ configuration and shear tested.

\section{EB Welding}

Sandwich coupons of each type had $2.86 \mathrm{~cm}$ by $0.64 \mathrm{~cm}$ tabs EB welded to them. The Re weld tabs were $0.32 \mathrm{~cm}$ thick, while the $\mathrm{C} 103$ tabs were $0.48 \mathrm{~cm}$ thick. A set of sandwich coupons had only $\mathrm{Re} E \mathrm{~EB}$ welded to the Re side, another set had only $\mathrm{C} 103 \mathrm{~EB}$ welded to the $\mathrm{C} 103$ side, and a third set of coupons had both, Re EB welded to the Re side and $\mathrm{C} 103 \mathrm{~EB}$ welded to the $\mathrm{C} 103$ side. The tabs were welded along the length of the coupons, as illustrated in figure 6 . The power settings for Re welding was nearly double the $\mathrm{C} 103$ settings. Full penetration was achieved on the welds. All three sets of coupons were then subjected to 100 thermal cycles, 21 to $1100^{\circ} \mathrm{C}$. The coupons were then EDMed into $\mathrm{Z}$ configuration and shear tested. Additionally, $\mathrm{C} 103$ $\mathrm{EB}$ welding was done with an explosively-bonded (lot \#2090) and a diffusion-bonded coupon. Thermal cycling was not performed on these two coupons. Rather, they were machined into $Z$ 's and shear tested directly.

\section{Shear Testing}

The Z-configured coupons tested in this study were used to get an order of magnitude estimate of bond strength and results were not traceable to ASTM standards. The shear coupons were pushed against a fixture (as shown in figure 7) in order to reduce bending moments that may have resulted from pulling the coupon. Two tests were conducted with as-received coupons of each set. One test was 
conducted with coupons from each set that had been thermally cycled and/or had EB welds.

\section{Joint Evaluation Results}

\section{Thermal Test Results}

All of the explosively-bonded (both lots) and diffusion-bonded coupons survived thermal cycling with no visible signs of degradation of the joint. This was true whether the coupons had EB welded tabs or not. The thermally-aged coupons also showed no apparent defects or degradation after testing.

\section{Shear Test Results}

The results of the shear testing are summarized in table II. Ultimate shear strength values are plotted in figure 8 and 9 for the explosively-bonded and diffusion-bonded coupons, respectively.

The as-received, explosively-bonded coupons from lot \#2090 had shear strengths of 281 and 310 $\mathrm{MPa}$. Shear strengths of the as-received coupons from lot \#2097 were 162 and $223 \mathrm{MPa}$. In both lots of explosively-bonded joints, thermally-cycled coupons with no welds and with $R$ e weld tabs had shear strengths within 30 percent of the as-received values. The lot \#2090 as-received coupons had higher shear strengths compared to the no weld and Re weld coupons, while the lot \#2097 as-received coupons had lower values. These results indicated scatter in the data.

Explosively-bonded coupons with either $\mathrm{C} 103$ weld tabs or $\mathrm{ClO} 3$ and $\mathrm{Re}$ weld tabs had a clear reduction in shear strength compared to the other coupons. Thermally-cycled coupons with $\mathrm{C} 103$ weld tabs had shear strengths of 53.8 and $75.8 \mathrm{MPa}$, for lots \#2090 and \#2097, respectively. Thermallycycled coupons with both $\mathrm{C} 103$ and $\mathrm{Re}$ weld tabs had 24.1 and $26.2 \mathrm{MPa}$ shear strength values, for lots \#2090 and \#2097, respectively. This large reduction in shear strengths could not be dismissed as data scatter. A lot \#2090 coupon with an C103 EB weld, that had not been thermally cycled broke during handling, before the shear test could be conducted.

The as-received diffusion-bonded coupons (tested two months apart from each other) had shear strengths of 199 and $348 \mathrm{MPa}$. The thermally-cycled coupon with the $R e$ weld tab had a shear strength of
$155 \mathrm{MPa}$, reduced from the as-received coupons. The two thermally-aged coupons had comparable shear strengths to the Re weld coupon. There was little difference between the coupons aged for 3 hours ( 122 $\mathrm{MPa}$ ) and 6 hours (134 $\mathrm{MPa}$ ). The cycled coupons with no welds and with both, $\mathrm{C} 103$ and $\mathrm{Re}$ weld tabs, had comparable shear strengths (87.6 and $82.7 \mathrm{MPa}$, respectively). These shear strengths were about 20 percent lower than the Re weld and thermally-aged coupons.

The shear strength of the thermally-cycled coupon with a C103 weld tab was $29.0 \mathrm{MPa}$, greatly reduced from the other coupons. Another diffusionbonded coupon had a C103 tab EB welded to it, but was not thermally cycled. This coupon was tested at the same time as the second as-received coupon. The C103 weld coupon had a shear strength of $247 \mathrm{MPa}$, while the second as-received coupon had a $348 \mathrm{MPa}$ shear strength, as mentioned above. While the $\mathrm{C} 103$ weld coupon had a 29 percent reduction of shear strength from the as-received coupon, both coupons had shear strengths above the group that was tested two months earlier. These differences again pointed to the presence of scatter in the data.

\section{Metallography}

The fracture surfaces of some of the coupons (indicated in Table I) were examined using EDS analysis. Although the elemental weight concentrations were not determined (the EDS spectra were not compared to standards), the relative concentrations of the elements could be discerned by comparing spectra peaks to the spectra of the $\mathrm{Re}$ and $\mathrm{C} 103$ base materials.

$\mathrm{Cu}$ was detected in all of the explosivelybonded fracture surfaces that were examined. The presence of $\mathrm{Cu}$ was probably due to the use of a brass wire in the initial EDMing of the explosively-bonded coupons. The diffusion-bonded coupons were EDMed later in the program using a Mo wire. Neither Mo nor $\mathrm{Cu}$ were found in the fracture surfaces of diffusion-bonded coupons.

Spectra close to the base $\mathrm{C} 103$ material were found on both fracture surfaces of the as-received, explosively-bonded coupons. There were also small peaks of $\mathrm{Re}$ and $\mathrm{Cu}$ found on both surfaces. The lack of strong Re peaks indicated that both coupons failed primarily in the $\mathrm{C} 103$ or a lightly alloyed version of 
C103. For the as-received, diffusion-bonded coupon, strong Re peaks were found on both fracture surfaces. and $\mathrm{a} \mathrm{Nb}$ peak was found on one of the fracture surfaces, indicating that some interdiffusion had taken place during the bonding process. However the high shear strength of the coupon ( $348 \mathrm{MPa}$ ) suggested that the small amount of interdiffusion did not adversely affect strength.

All of the thermally-cycled coupons that were examined had higher concentrations of $\mathrm{Hf}$ than were present in the $\mathrm{C} 103$ base material. Undoubtedly the high levels of $\mathrm{Hf}$ were due to diffusion from $\mathrm{C} 103$ to Re during thermal cycling. There was concern that diffusion of $\mathrm{Hf}$ into $\mathrm{Re}$ was creating a brittle intermetallic and that was responsible for the degradation of strength seen in the C103 EB welded coupons. However, high levels of $\mathrm{Hf}$ were found in fracture surfaces of lot $\# 2090$, explosively-bonded coupons with both no weld tabs and with a Re weld tab. These coupons had relatively high shear strengths. No correlation could be found relating the degradation of shear strength and the concentration of Hf.

The degradation of shear strength, then, seemed to be related to the $\mathrm{EB}$ welding of $\mathrm{C} 103$ tabs. One concern was that the $\mathrm{EB}$ welding was somehow softening the $\mathrm{C} 103$ base material. The $\mathrm{C} 103$ hardnesses on two lot \#2090, explosively-bonded coupons were determined. Both coupons had been thermally-cycled, but one had no EB welds, while the other had a C103 weld tab. The Rockwell B hardnesses of the no weld and $\mathrm{C} 103$ weld coupons were similar, 77.4 and 74.3 , respectively. The Rockwell B hardnesses of the Re were also similar to each other, 106.8 and 104.9, respectively, for the no weld and $\mathrm{C} 103$ weld coupons. The similar hardnesses between coupons indicated that $\mathrm{EB}$ welding of $\mathrm{C} 103$ was not having adverse effects on the base material.

Another concern with EB welding $\mathrm{C} 103$ was the possible formation of the known brittle Re-Nb intermetallic phase (between 63 and 76 weight percent Re). Coupons were clamped at one end during the welding, providing for a poor heat sink. Although the Re EB welding involved higher power settings, the Re with its high thermal conductivity was able to dissipate heat better than $\mathrm{C103}$. The C103 EB welding, then, could have raised the temperature at the bond line above $2162^{\circ} \mathrm{C}$ at which the brittle intermetallic forms. This would explain why (with one exception) only the coupons with $\mathrm{Cl03}$ weld tabs had low shear strengths. If this were the explanation, the brittle intermetallic could easily be avoided by simply providing a better heat sink for EB welding and/or a bi-metal joint design with a geometry that would keep the bond line temperature below $2162{ }^{\circ} \mathrm{C}$.

In order to separate the effects of thermal cycling and EB welding, an explosively-bonded (lot \#2090) coupon and a diffusion-bonded coupon had C103 tabs EB welded to them, but were not thermally cycled. The explosively-bonded coupon broke during handling before shear testing could be conducted, however it was examined using EDS just as the diffusion-bonded coupon was. The EB welded (C103) side of both coupons had high peaks of Re, along with the expected peaks of $\mathrm{Nb}$. The non-EB welded $(\mathrm{Re})$ side fracture surfaces had lower peaks of $\operatorname{Re}$ than seen in the base Re, but significant peaks of $\mathrm{Nb}$. Examination of the EDS spectra of the other coupons with $\mathrm{Cl} 103$ weld tabs showed high peaks of $\mathrm{Re}$ and $\mathrm{Nb}$ on both fracture surfaces. The lot \#2090, explosively-bonded coupons with no weld tabs and Re weld tab also showed high peaks of Re on both fracture surfaces. However the peaks of $\mathrm{Nb}$ were less than those seen on the coupons with $\mathrm{C} 103$ weld tabs. The common denominator to coupons with low strength would appear to be a spectra containing high peaks of Re and $\mathrm{Nb}$ on both fracture surfaces. This would suggest that a $\mathrm{Re}-\mathrm{Nb}$ intermetallic was responsible for the degradation shear strength.

\section{Concluding Remarks}

Explosive bonding and diffusion bonding appear to be viable options for creating bi-metal, Reto-C103 joints. Re-to- $\mathrm{Cl} 03$ joint coupons, formed by explosive and diffusion bonding, were evaluated in thermal and shear testing. Explosively and diffusion bonded coupons survived 100 thermal cycles from 21 to $1100^{\circ} \mathrm{C}$ and thermal aging at $1100^{\circ} \mathrm{C}$ for 3 and 6 hours intact and with no visible signs of degradation. As-received coupons of explosively-bonded joints had ultimate shear strengths of 281 and $310 \mathrm{MPa}$ for one lot (\#2090) and 162 and $223 \mathrm{MPa}$ for another lot (\#2097). As-received coupons of diffusion-bonded joints had ultimate shear strengths of 199 and 348 $\mathrm{MPa}$. The wide range of values indicated scatter in the data. With one exception, the thermally-treated 
and $\mathrm{Re}$ weld tab coupons were slightly reduced or within the range of the as-received values, regardless of whether they were explosively or diffusion bonded.

Coupons with $\mathrm{C} 103$ weld tabs, whether alone or with $\mathrm{Re}$ tabs, experienced a significant reduction in strength that could not be dismissed as data scatter. This was true with the explosive and diffusion bonded coupons. Examination of EDS spectra on the fracture surfaces of thermally-cycled coupons showed high levels of $\mathrm{Hf}$, regardless of whether the coupon had high or low shear strength. Diffusion of Hf from C103 into Re undoubtedly occurred during thermal cycling, but it could not be correlated with the low strengths of the $\mathrm{C} 103$ weld coupons. The low strength was more likely related to the EB welding process itself, where coupons were clamped at one end, providing a poor heat sink. The $\mathrm{C} 103$ base material could not dissipate heat as well as $\mathrm{Re}$ can. As a result, the temperature at the bond line may have risen above $2162^{\circ} \mathrm{C}$, forming the brittle $\mathrm{Re}-\mathrm{Nb}$ intermetallic. EDS spectra of the low strength coupons had significant peaks of $\mathrm{Re}$ and $\mathrm{Nb}$ on both fracture surfaces, which suggested at least some intermetallic of $\mathrm{Re}$ and $\mathrm{Nb}$ had formed. This problem can be avoided by simply providing a better heat sink during EB welding and/or tailoring the joint design to dissipate heat better in the $\mathrm{C} 103$.

\section{Acknowlegdements}

The author would like to express his deep appreciation to Douglas Wolf of the Surface Science Laboratory at the University of Dayton for conducting the thermal and shear testing and the EDS analyses in this study.

\section{References}

1. Wooten, J.R. and Lansaw, P.T.: High Temperature, Oxidation-Resistant Thruster Research, Final Report, Contract NAS3-24643, CR-185233, February 1990.

2. Schoenman, L: $4000{ }^{\circ} \mathrm{F}$ Materials for Low Thrust Rocket Engines, AIAA Paper 93-2406, June 1993.

3. Jassowski, D.M. and Gage, M.L.: Advanced Small Rocket Chambers, Option 1 Final Report, Contract NAS3-25646, CR-191014, August 1992.
4. Jassowski, D.M.: Advanced Small Rocket Chambers, Option 3 Final Report, Contract NAS325646, CR-195435, November 1994.

5. Chazen, M.L., etc. al.: Space Storable Rocket Technology Program, Option 1 Final Report, Contract NAS3-26246, CR-191171, August 1993.

6. Chazen, M.L., etc. al: Space Storable Rocket Technology Program, Option 2 Final Report, Contract NAS3-26246, to be published.

7. Brasher, D.: Explosive Welding: Principles and Potentials, Outlook, Volume 15, Number 2, 2nd Quarter 1994, pp. 2 \& 6.

8. Messler, Jr., R.W.: Joining of Advanced Materials, ISBN 0-7506-9008-9, published by Butterworth-Heinemann, 1993.

9. Horak, J.A. and Kangilaski, M.: Effects of Irradiation on the Tensile Properties of Rhenium, Oak Ridge National Laboratory Report ORNL/TM12360, April 1993. 
Table I: Matrix for Re-to-C103 Joint Evaluation

$\begin{aligned} & \text { Coupon } \\ & \text { As-Received }\end{aligned}$
$\begin{aligned} & \frac{\text { Explosive Bond }}{2090} \\ & 2^{\mathrm{a}}\end{aligned}$


Table II: Shear Testing Results

\begin{tabular}{|c|c|c|c|}
\hline Joining Technique & Thermal Treatment & EB Weld Tab & Ultimate Shear Strength (MPa) \\
\hline \multirow{7}{*}{ Explosive Bond, Lot \#2090 } & None & None & 310 \\
\hline & None & None & 281 \\
\hline & Cycled & None & 219 \\
\hline & Cycled & $\operatorname{Re}$ & 212 \\
\hline & Cycled & $\mathrm{C} 103$ & 53.8 \\
\hline & Cycled & $\mathrm{Re} \& \mathrm{Cl} 03$ & 24.1 \\
\hline & None & $\mathrm{C} 103$ & Coupon Broke During Handling \\
\hline \multirow[t]{6}{*}{ Explosive Bond, Lot \# 2097} & None & None & 223 \\
\hline & None & None & 162 \\
\hline & Cycled & None & 246 \\
\hline & Cycled & $\operatorname{Re}$ & 231 \\
\hline & Cycled & $\mathrm{C} 103$ & 75.8 \\
\hline & Cycled & $\mathrm{Re} \& \mathrm{C} 103$ & 26.2 \\
\hline \multirow[t]{9}{*}{ Diffusion Bond } & None & None & 199 \\
\hline & None & None & 348 \\
\hline & Cycled & None & 87.6 \\
\hline & Cycled & $\operatorname{Re}$ & 155 \\
\hline & Cycled & $\mathrm{C} 103$ & 29.0 \\
\hline & Cycled & $\mathrm{Re} \& \mathrm{C} 103$ & 82.7 \\
\hline & None & $\mathrm{C} 103$ & 247 \\
\hline & $3 \mathrm{hrs} @ 1100^{\circ} \mathrm{C}$ & None & 122 \\
\hline & $6 \mathrm{hrs} @ 1100^{\circ} \mathrm{C}$ & None & 134 \\
\hline
\end{tabular}

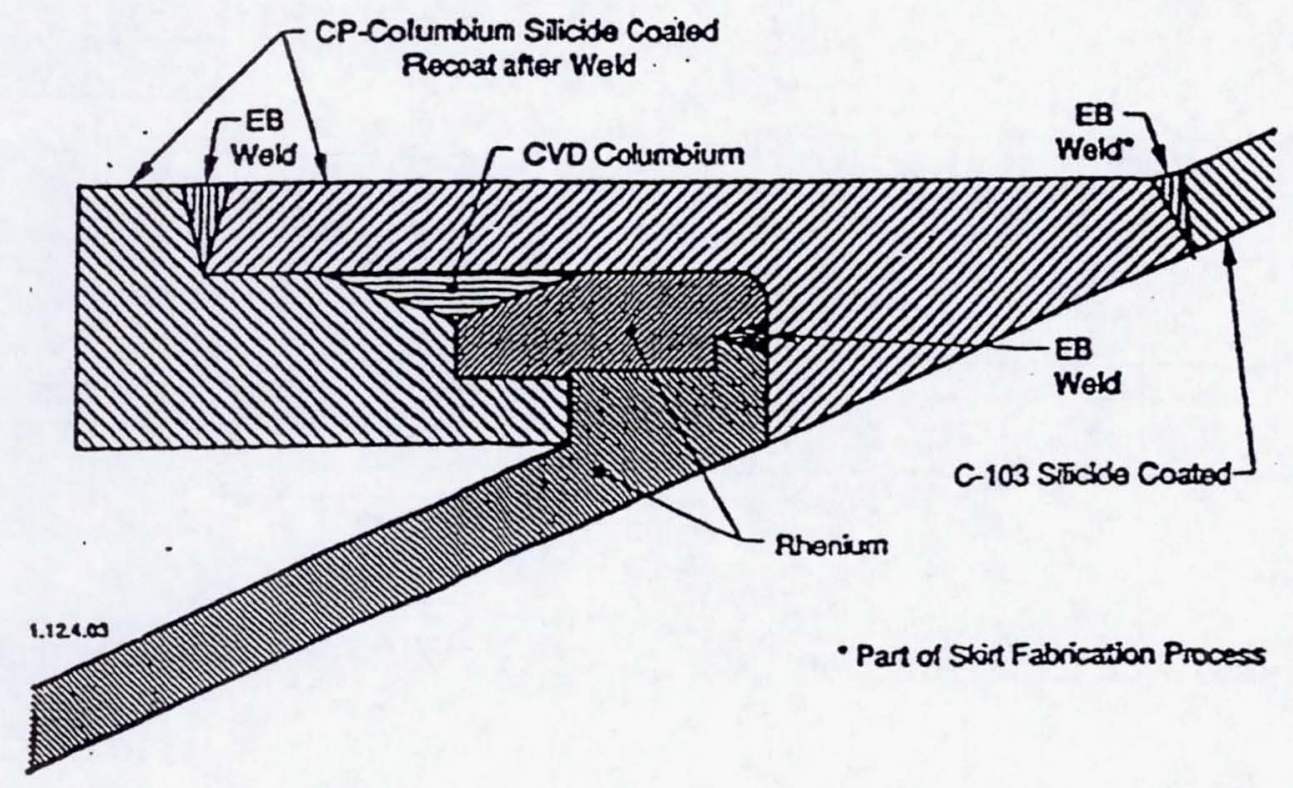

Figure 1: Re-to-C103 Nozzle Joint for Flight-Type, $440 \mathrm{~N}$ Engine (ref. 4) 


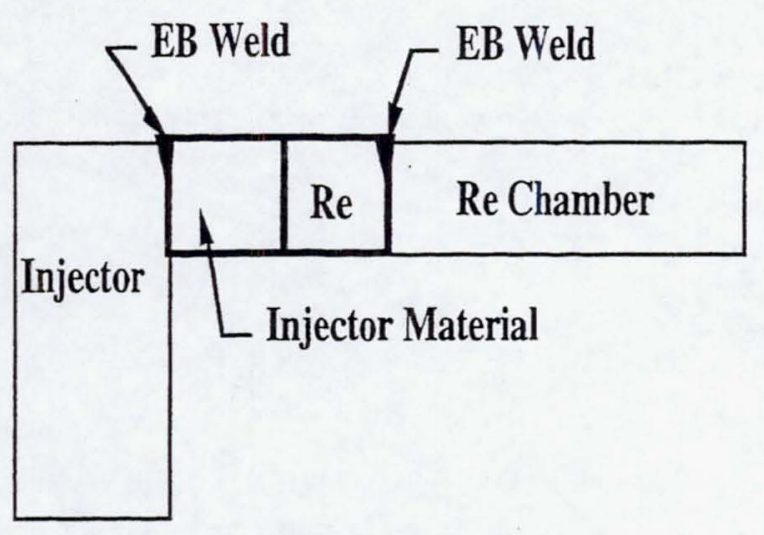

Bi-Metal Ring (in Bold)

Figure 2: Examples of Bi-Metal Joint Configurations

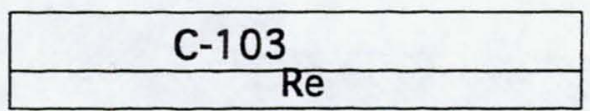

0.32

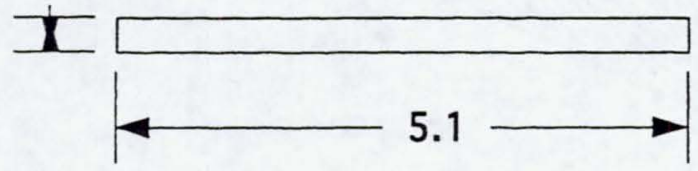

\section{Sandwich Configuration}

Dimensions in centimeters

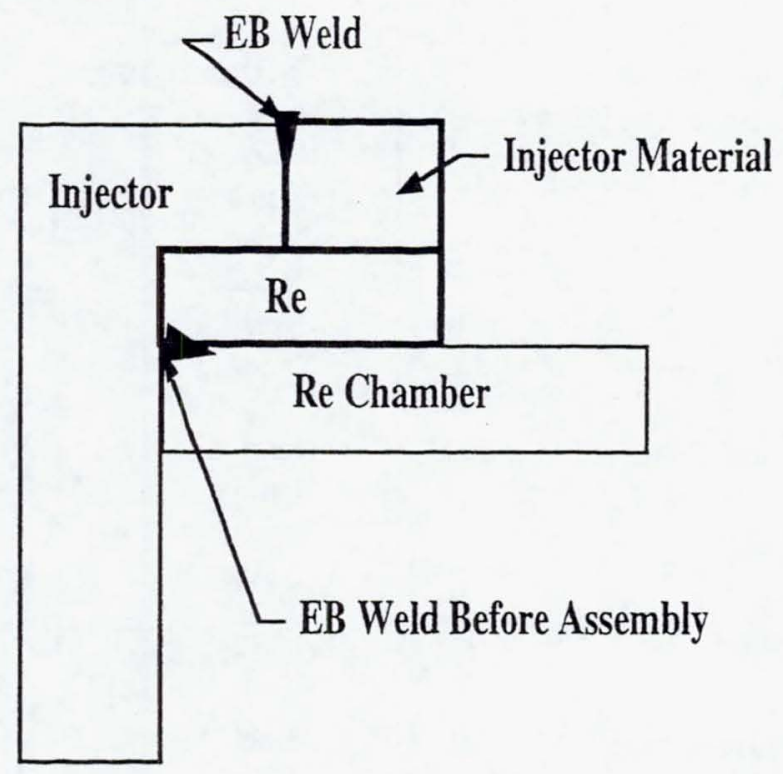

Bi-Metal Tube (in Bold)
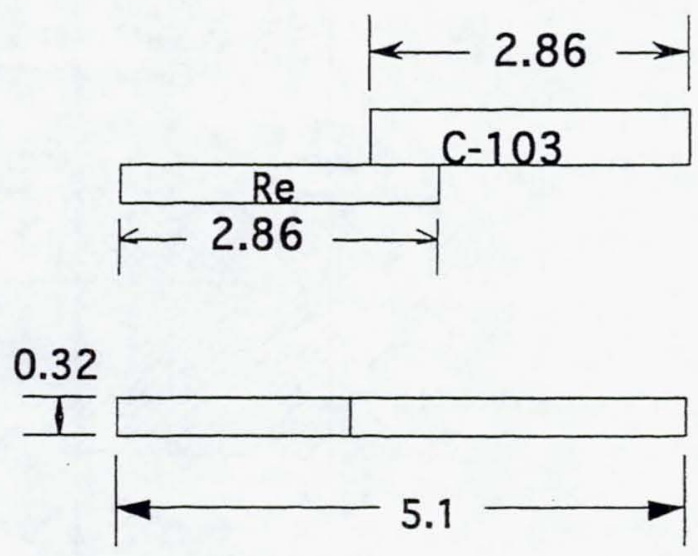

"Z" (Shear) Configuration

Figure 3: Joint Coupon Configurations 


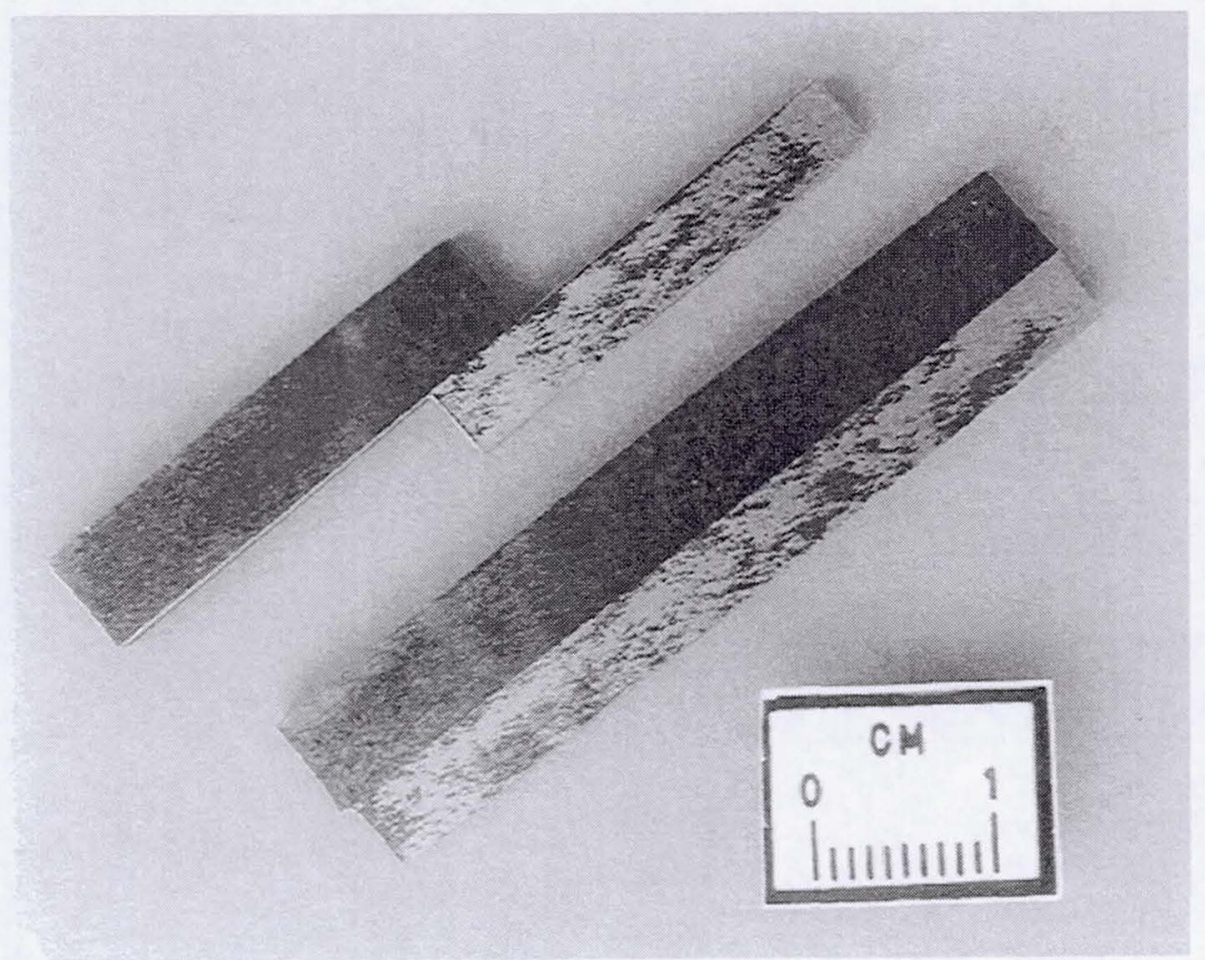

Figure 4: Explosively-Bonded Joint Coupons

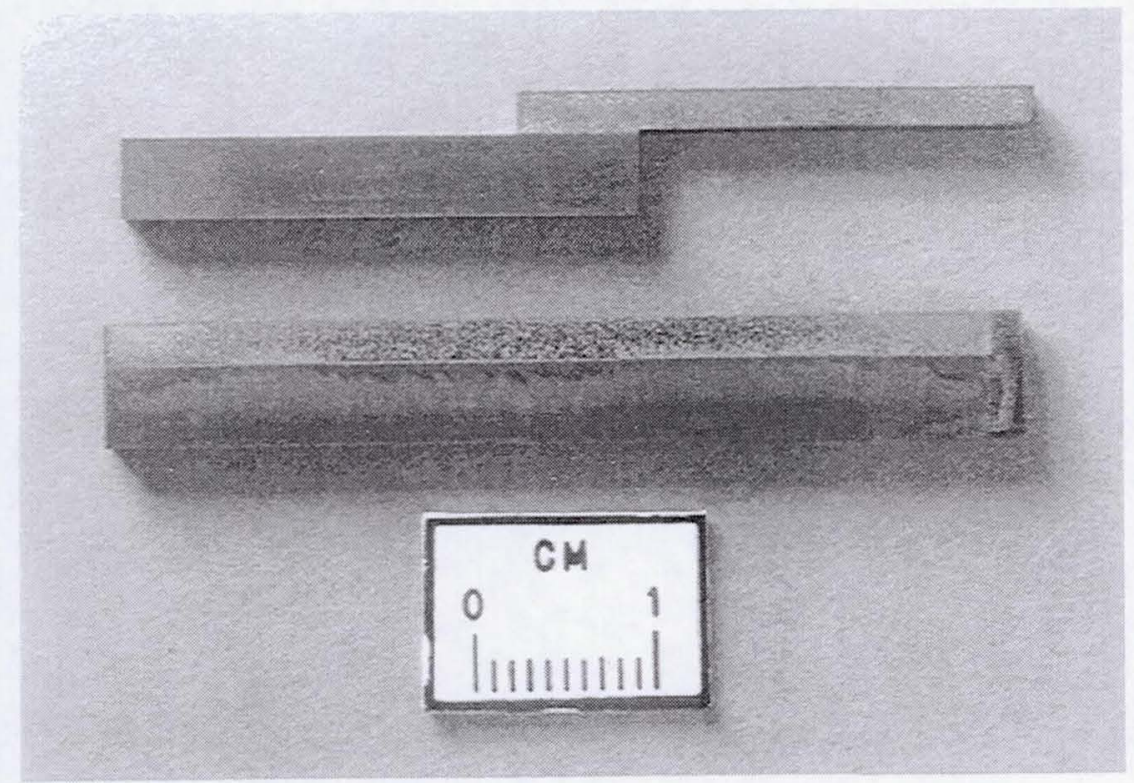

Figure 5: Diffusion-Bonded Joint Coupons 


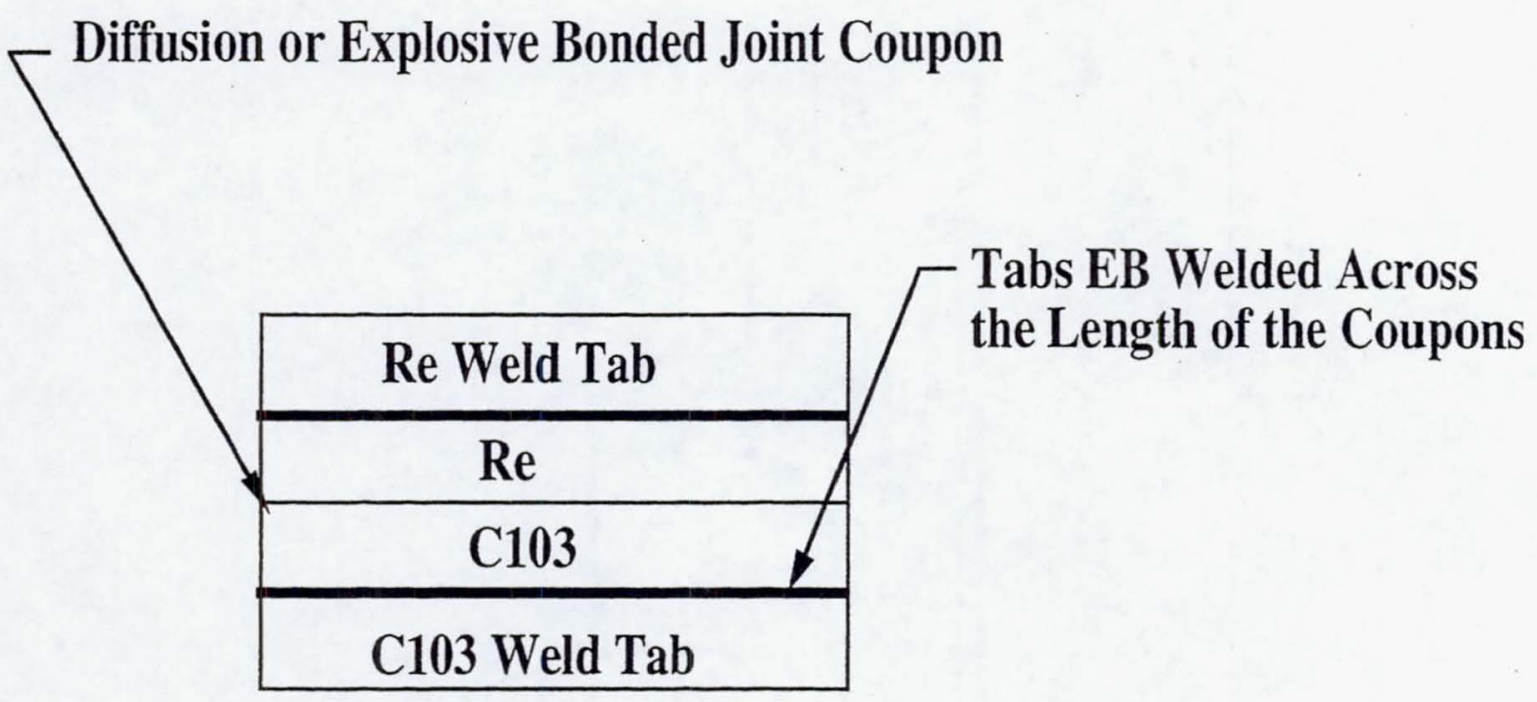

Figure 6: EB Welding of Tabs to Coupons

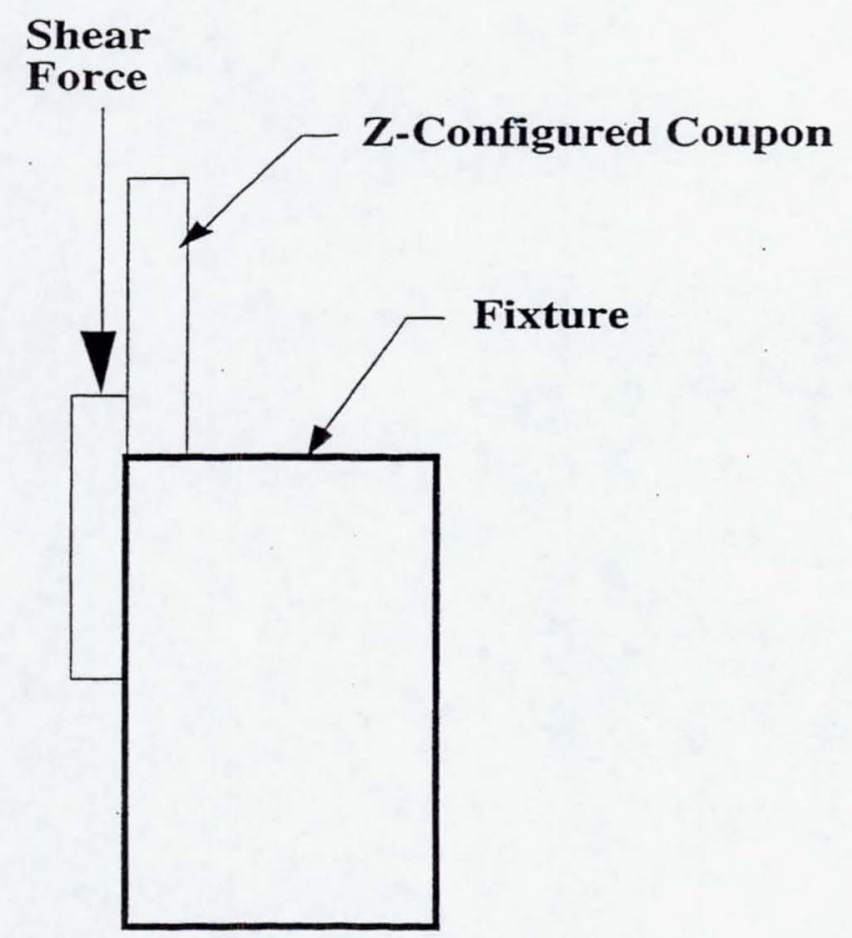

Figure 7: Shear Testing of Coupons 


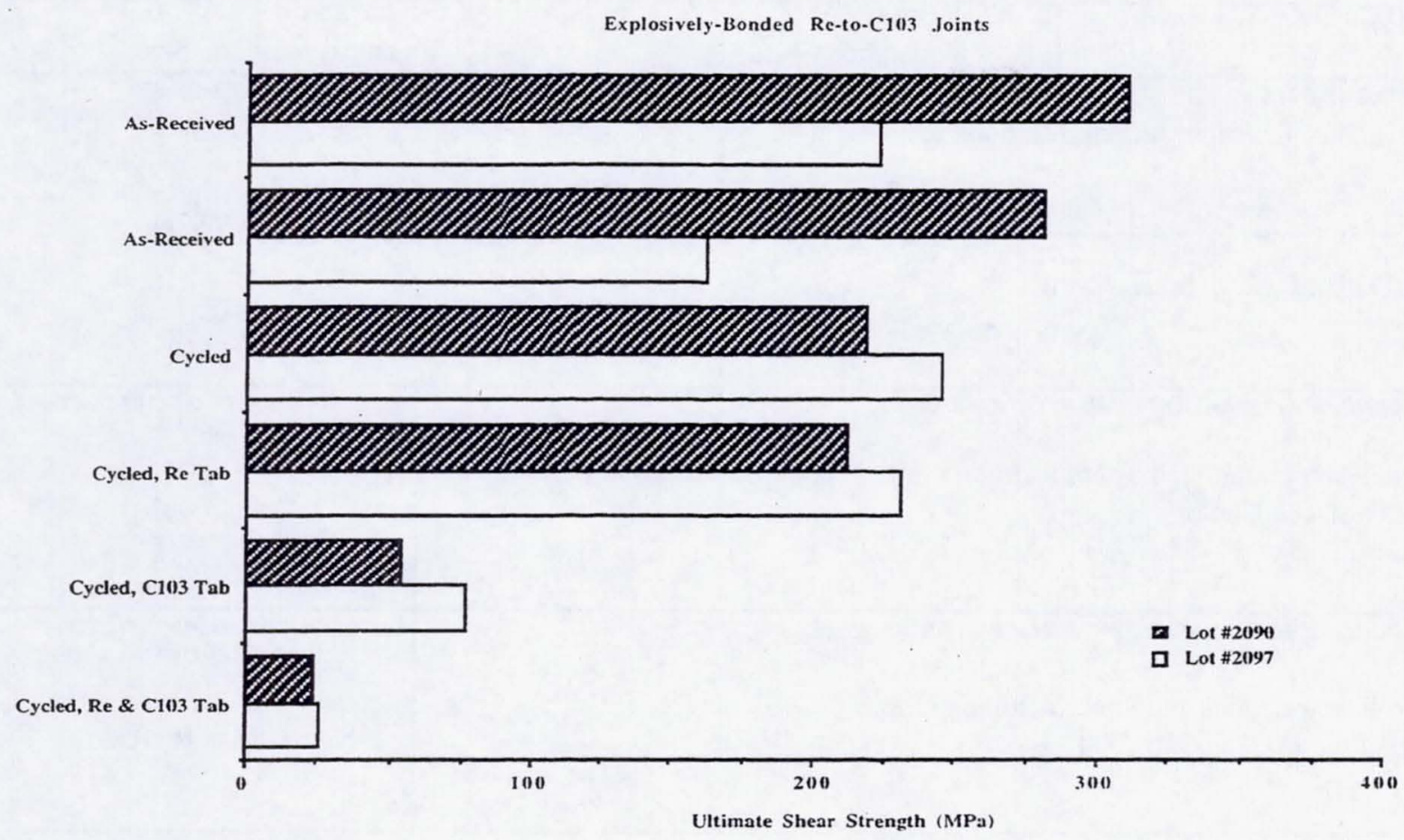

Figure 8: Ultimate Shear Strength for Explosively-Bonded Coupons

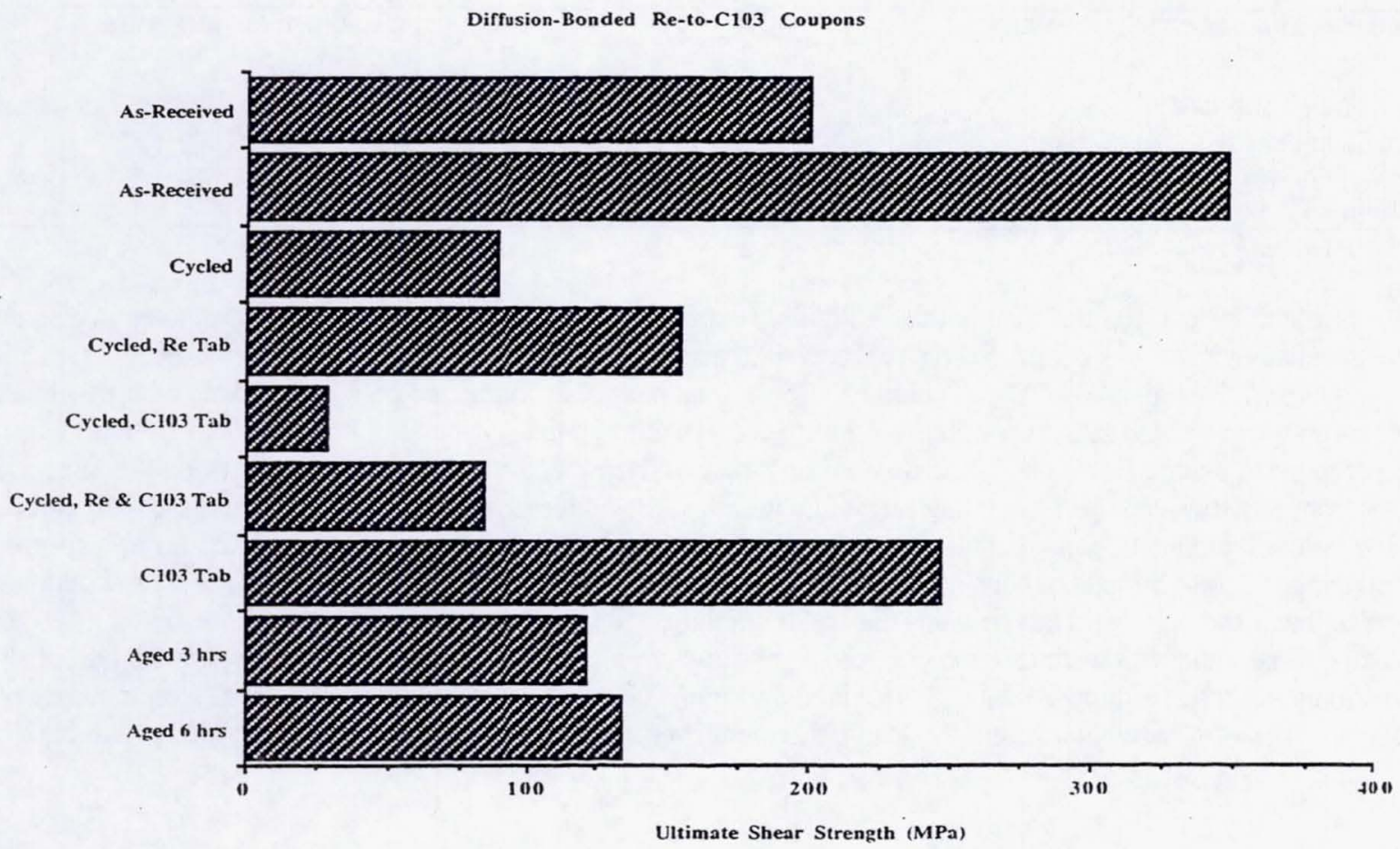

Figure 9: Ultimate Shear Strength for Diffusion-Bonded Coupons 


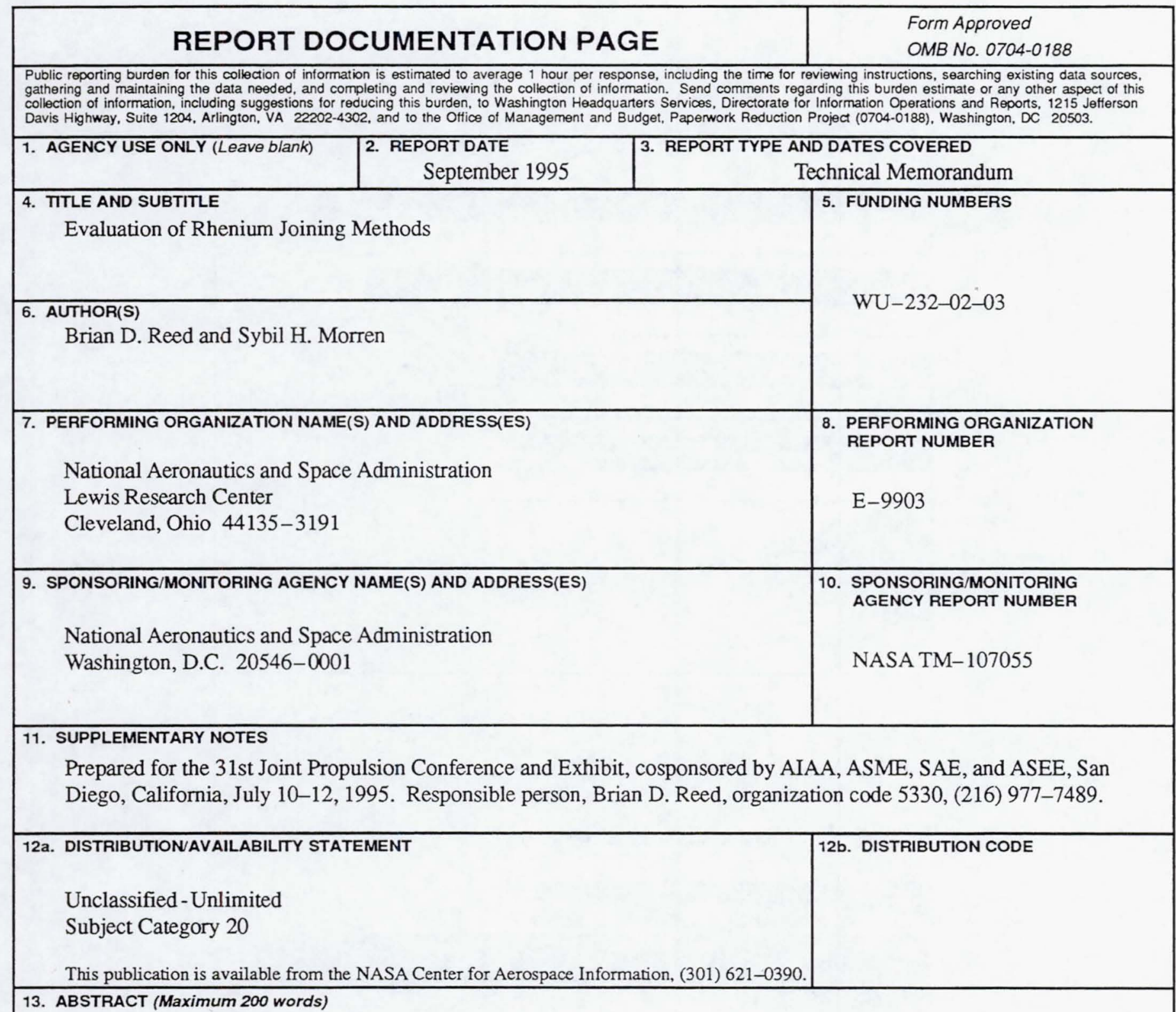

13. ABSTRACT (Maximum 200 words)

Coupons of rhenium-to-C103 flat plate joints, formed by explosive and diffusion bonding, were evaluated in a series of shear tests. Shear testing was conducted on as-received, thermally-cycled (100 cycles, from 21 to $1100^{\circ} \mathrm{C}$ ), and thermally-aged $\left(3\right.$ and $6 \mathrm{hrs}$ at $1100^{\circ} \mathrm{C}$ ) joint coupons. Shear tests were also conducted on joint coupons with rhenium and/or $\mathrm{C} 103$ electron beam welded tabs to simulate the joint's incorporation into a structure. Ultimate shear strength was used as a figure of merit to assess the effects of the thermal treatment and the electron beam welding of tabs on the joint coupons. All of the coupons survived thermal testing intact and without any visible degradation. Two different lots of as-received, explosively-bonded joint coupons had ultimate shear strengths of 281 and $310 \mathrm{MPa}$ and 162 and $223 \mathrm{MPa}$, respectively. As-received, diffusion-bonded coupons had ultimate shear strengths of 199 and $348 \mathrm{MPa}$. For the most part, the thermally-treated and rhenium weld tab coupons had shear strengths slightly reduced or within the range of the as-received values. Coupons with $\mathrm{C} 103$ weld tabs experienced a significant reduction in shear strength. The degradation of strength appeared to be the result of a poor heat sink provided during the electron beam welding. The C103 base material could not dissipate heat as effectively as rhenium, leading to the formation of a brittle rhenium-niobium intermetallic.

\begin{tabular}{|c|c|c|c|}
\hline \multirow{2}{*}{\multicolumn{3}{|c|}{$\begin{array}{l}\text { 14. SUBJECT TERMS } \\
\text { Joining; Bonding; Welding; Rhenium; Radiation-cooled rockets }\end{array}$}} & \multirow{2}{*}{$\begin{array}{l}\text { 15. NUMBER OF PAGES } \\
15 \\
\text { 16. PRICE CODE } \\
\text { A03 } \\
\text { 20. LIMITATION OF ABSTRACT }\end{array}$} \\
\hline & & & \\
\hline $\begin{array}{l}\text { 17. SECURTY CLASSIFICATION } \\
\text { OF REPORT } \\
\text { Unclassified }\end{array}$ & $\begin{array}{l}\text { 18. SECURITY CLASSIFICATION } \\
\text { OF THIS PAGE } \\
\text { Unclassified }\end{array}$ & $\begin{array}{l}\text { 19. SECURITY CLASSIFICATION } \\
\text { OF ABSTRACT } \\
\text { Unclassified }\end{array}$ & 20. LIMITATION OF ABSTRACT \\
\hline
\end{tabular}

